\title{
PENGARUH KOMPENSASI DAN LINGKUNGAN KERJA TERHADAP KINERJA KARYAWAN PADA CV. RODA JATI KARANGANYAR TAHUN 2016
}

\section{Rukmini}

\author{
STIE AAS Surakarta \\ Email : rukminidra@yahoo.co.id
}

\begin{abstract}
ABSTRAK
Karyawan merupakan sumber daya yang sangat penting bagi kelangsungan hidup perusahaan, sehingga perlu mendapat perhatian hal hal yang berkaitan dengan kinerja karyawan dalam rangka mencapai tujuan perusahaan. Tujuan dari penelitian adalah untuk mengetahui pengaruh faktor kompensasi dan lingkungan kerja terhadap kinerja karyawan dan faktor yang paling dominan dalam mempengaruhi kinerja karyawan pada CV. Roda Jati Karanganyar. Jenis Penelitian yang digunakan adalah deskriptif kualitatif dan deskriptif kuantitatif. Sesuai dengan tujuan penelitian ini maka sampel yang digunakan adalah karyawan CV. Roda Jati Karanganyar. Melalui penelitian pendahuluan ini diharapkan selain menghasilkan rumusan penelitian tindak lanjut utamanya adalah menjadi bahan referensi perusahaan untuk dapat menentukan strategi pengembangan sumber daya manusia untuk mencapai tujuan perusahaan
\end{abstract}

Kata kunci : $\quad$ kompensasi, lingkungan kerja dan kinerja karyawan

\section{PENDAHULUAN}

Persaingan yang semakin ketat dalam dunia usaha saat ini merupakan cambuk bagi perusahaan untuk dapat mencari strategi yang tepat dalam mempertahankan kehidupan perusahaan. Salah satu usaha yang dilakukan perusahaan yaitu dengan mengelola dan menggunakan sumber daya manusia dengan baik dan benar. Sumber daya manusia merupakan bagian yang cukup penting dalam pencapaian tujuan organisasi baik itu perusahaan besar maupun kecil. Organisasi apapun bentuknya membutuhkan manajemen yang mampu mengakomodir setiap perubahan yang terjadi.

Sebagai roda penggerak organisasi manusia harus senantiasa diberdayakan dan dikembangkan agar menjadi sumber daya yang memiliki daya saing. Kualitas sumber daya menjadi fokus utama apabila organisasi ingin mempercepat tercapainya visi dan misi yang ditetapkan. Dinamika perubahan bisnis menuntut organisasi mampu mensikapi dengan cepat dan tepat demi kepentingan masyarakat. 
Untuk itu pengelolaan SDM dalam sebuah perusahaan menjadi sangat penting sehingga harus mendapatkan prioritas utama, jika perusahaan itu ingin maju dan menjadi leader, juga untuk menghasilkan produk dan jasa yang dapat dipasarkan dan mencapai tujuan sesuai yang diharapkan, sumber daya terdiri dari modal, manusia, mesin. Apabila semua dapat dikelola dengan baik maka perusahaan dapat dengan mudah untuk mencapai tujuannya. Asset paling utama yang harus diperhatikan perusahaan adalah sumber daya manusia, karena manusia merupakan sumber daya yang selalu ada dalam organisasi dan sangat penting peranannya dalam menentukan tercapai tidaknya tujuan suatu perusahaan.

Karena pentingnya sumber daya
manusia bagi kelangsungan hidup dan kemajuan perusahaan, maka perusahaan harus memberikan perhatian khusus pada faktor karyawan dan sudah wajar jika perusahaan memandang sumber daya manusia lebih dari sekedar asset perusahaan tetapi sebagai mitra dalam berusaha. Sebagai mitra dalam berusaha dalam hal ini karyawan, sudah sewajarnya jika perusahaan harus dapat bersikap adil atas apa yang telah diberikan karyawan untuk perusahaan, karena setiap karyawan berhak mendapatkan penghargaan dan perlakuan yang adil dari pimpinan sebagai timbal balik atas jasa yang diberikan kepada perusahaan, dan karyawan dapat termotivasi untuk bekerja semaksimal mungkin. Untuk mendorong semangat kerja diperlukan adanya hubungan yang saling menguntungkan antara perusahaan dan karyawan. Karyawan memberikan prestasi kerja yang baik untuk kemajuan perusahaan, sedangkan perusahaan memberikan kompensasi yang sesuai dengan prestasi kerja yang telah diberikan karyawan terhadap perusahaan.

Pemberian kompensasi sangat penting bagi karyawan. besarnya kompensasi bagi mereka mencerminkan ukuran nilai karya mereka diantara para karyawan itu sendiri, keluarga dan masyarakat. Tingkat kompensasi absolut karyawan menentukan skala kehidupannya, sedangkan kompensasi relatif menunjukkan status, martabat, dan harga diri mereka. Jadi bila para karyawan memandang kompensasi mereka tidak memadai, prestasi kerja, motivasi dan kepuasan kerja mereka biasa turun secara dramatis. Tujuan kompensasi yang dilakukan perusahaan adalah untuk menghargai prestasi kerja karyawan, menjamin keadilan antara karyawan, mempertahankan pegawai, memperoleh karyawan yang kompeten dan bermutu, sehingga dapat memotivasi setiap karyawan untuk bekerja lebih baik.( Martoyo : 1999)

Selain kompensasi, faktor lain yang perlu diperhatikan perusahaan adalah lingkungan kerja, Lingkungan Kerja menurut Rivai (2006:165) adalah keseluruhan sarana dan prasarana yang ada di sekitar karyawan yang sedang melakukan pekerjaan itu sendiri. Lingkungan kerja ini akan meliputi tempat kerja, fasilitas dan alat bantu kerja, kebersihan, pencahayaan dan ketenangakerjaan. Lingkungan kerja sangat berkaitan erat dengan tinggi rendahnya kepuasan karyawan, dan apabila lingkungan kerja baik, maka dapat memberikan pengaruh yang positif terhadap kinerja karyawan dan 
sebaliknya. Suatu kondisi kerja dikatakan baik atau sesuai apabila sumber daya manusia dapat melaksanakan kegiatan secara optimal, sehat, aman dan nyaman. Kompensasi dan lingkunga kerja merupakan faktor yang berpengaruh terhadap kinerja karyawan.

Kinerja seorang karyawan merupakan hal yang bersifat individual, karena setiap karyawan mempunyai tingkat kemampuan yang berbeda beda dalam mengerjakan tugasnya. Pihak manajemen dapat mengukur karyawan atas unjuk kerjanya berdasarkan kinerja dari masing - masing karyawan. Kinerja adalah sebuah aksi, bukan kejadian. Aksi kinerja itu sendiri terdiri dari banyak komponen dan bukan merupakan hasil yang dapat dilihat pada saat itu juga. Pada dasarnya kinerja merupakan sesuatu hal yang bersifat individual, karena setiap karyawan memiliki tingkat kemampuan yang berbeda dalam mengerjakan tugasnya. Kinerja tergantung pada kombinasi antara kemampuan, usaha, dan kesempatan yang diperoleh.

Seperti halnya yang terjadi pada perusahaan manufaktur yang bergerak di bidang industri mebel CV Roda Jati Karanganyar dimana sampai saat ini memiliki sekitar 80 karyawan dengan berbagai karakter dan latar belakang yang berbeda dan keluar masuknya karyawan serta kemungkinan adanya karyawan yang senior yang mengabdi pada perusahaan tersebut dalam waktu yang cukup lama. Sehingga perlu mendapat perhatian masalah pemberian kompensasi dan lingkungan kerja yang merupakan beberapa faktor yang mempengaruhi kinerja karyawan di perusahaan ini.

\section{TINJAUAN PUSTAKA}

\section{Pengertian SDM}

Pengertian SDM Menurut Hadawi Nawawi (2001)

"manajemen sumber daya manusia adalah prose mendayagunakan manusia sebagai tenaga kerja secar manusiawi, agar potensi fisik dan psikis yang dimilikinya berfungsi maksimal bagi pencapaian tujuan perusahaan".

\section{Tujuan Manajemen Sumber Daya Manusia}

\section{Produktif}

Produktif pada dasarnya bukan hasil proses produksi dan hal tersebut adalah indikator bahwa tujuan produktifitas dalam manajemen sumber daya manusia sudah tercapai. Tersedianya tenaga kerja yang produktif dapat dicapai bilamana sejak rekrutmen, seleksi, penempatan, pengembangan karier dilakukan secara tepat, sehingga para pekerja yang tersedia merupakan sumber daya manusia yang produktif.

\section{Keamanan dan Kepatuhan Kerja}

Bertujuan untuk tercapainya kondisi sumber daya manusi yang mendukung kemampuannya mewujudkan produktifitas yang tinggi dalam bekerja, baik dari segi fisik maupun psikis, yaitu perasaan aman dan puas dalam bekerja, karena berada dalam posisi yang menyenangkan dan diperlakukan sesuai dengan harkat dan martabat sebagai manusia, sehingga mampu meningkatkan 
kesediaan bekerja keras dengan moral dan disiplin kerja yang tinggi.

\section{Kualitas Sumber Daya Manusia}

Mewujudkan sumber daya manusia yang berkualitas, agar mampu mewujudkan tujuan bisnis berupa produk dan pelayanan yang berkualitas.

\section{Keuntungan dan Manfaat Lainnya}

Bertujuan menyediakan dan mengembangkan sumber daya manusia yang mampu mewujudkan keuntungan dan manfaat lainnya bagi organisasi, agar pekerja memperoleh pembagian yang layak dari keuntungan dan manfaat lainnya yang dicapai yang dicapai/diperoleh oleh perusahaan.

\section{Fungsi Manajemen Sumber Daya Manusia}

Fungsi manajemen sumber daya manusia adalah sebagai berikut ( Husein Umar : 2004 )

\section{Pelayanan (Service)}

Untuk memberikan pelayanan kepada para pekerja dalam rangka meningkatkan dan mengembangkan kemampuannya, agar menjadi sumber daya manusia yang kompetitif. Pelayanan diberikan dengan menyelenggarakan program-program yang berisi kegiatan perluasan wawasan, perbaikan sikap, penambahan pengetahuan dan keterampilan dan upaya-upaya menciptakan rasa aman dan kepuasan kerja.

\section{Kontrol}

Untuk mengontrol perwujudan kontribusi para pekerja dalam mencapai tujuan bisnis perusahaan, melalui proses partisipasi diri dan cara memberikan kesempatan untuk berpartisipasi dalam meningkatkan produktifitas.

\section{Pengembangan}

Proses memberikan kesempatan pada pekerja untuk meningkatkan pengetahuan, keterampilan dan profesionalitasnya dalam bekerja melalui berbagai kegiatan berupa usaha pekerja yang bersangkutan dengan mendapat dorongan dan atau disponsori oleh perusahaan, bisa dalam bentuk memberikan izin atau tugas belajar ke lembaga yang lebih tinggi, menyelenggarakan pelatihan dan lain-lain.

\section{Kompensasi dan Akomodasi}

Untuk mewujudkan dan mengembangkan rasa aman dan kepuasan kerja dilingkungan para pekerja yang memungkinkan para pekerja bersedia bekerja keras dengan disiplin dan moral kerja yang tinggi.

\section{Advis}

Berupa pemberian informasi, bantuan, saran dan pendapat kepada para manajer dan bahkan manajer tertinggi dalam mengambil keputusan atau menyelesaikan masalah dilingkungan masing-masing, karena manajer setiap bidang tidak dapat melepaskan diri dari tanggung jawab sumber daya manusia diunit kerjanya.

\section{Pengertian Kompensasi}

Kompensasi adalah segala sesuatu yang diterima para karyawan sebagai balas jasa 
untuk kerja mereka. Kompensasi juga merupakan salah satu cara yang paling efektif bagi departemen personalia guna meningkatkan prestasi kerja, motivasi serta kepuasan kerja karyawan. Sistem kompensasi yang baik akan mampu memberikan kepuasan bagi karyawan dan memungkinkan perusahaan memperoleh, mempekerjakan, dan mempertahankan karyawan

\section{Fungsi dan Tujuan Kompensasi}

Martoyo (1994) berpendapat bahwa tujuan kompensasi adalah:

a. Pemenuhan kebutuhan ekonomi karyawan atau sebagai jaminan economic security bagi karyawan.

b. Mendorong agar karyawan lebih baik dan lebih giat.

c. Menunjukkan bahwa perusahaan mengalamikemajuan

d. Menunjukkan penghargaan dan perlakuan adil organisasi terhadap karyawannya (adanya keseimbangan antara input yang diberikan karyawan terhadap perusahaan dan output atau besarnya imbalan yang diberikan perusahaan kepada karyawan).

Sedangkan fungsi diberikan kompensasi adalah :

a. Penggunaan SDM secara lebih efisien dan lebih efektif Kompensasi yang tinggi pada seorang karyawan mempunyai implikasi bahwa organisasi memperoleh keuntungan dan manfaat maksimal dari karyawan yang bersangkutan karena besarnya kompensasi sangat ditentukan oleh tinggi/rendahnya produktivitas kerja karyawan yang bersangkutan.

b. Mendorong stabilitas dan pertumbuhan ekonomi Sistem pemberian kompensasi yang baik secara langsung dapat membantu stabilitas organisasi dan secara tidak langsung ikut andil dalam mendorong stabilitas dan pertumbuhan ekonomi. Sebaliknya pemberian kompensasi yang kurang baik dapat menyebabkan gejolak di kalangan karyawan akibat ketidakpuasan. Pada gilirannya gejolak ketidakpuasan ini akan menimbulkan kerawanan ekonomi

\section{Penggolongan dan jenis Kompensasi}

\section{Penentuan besarnya kompensasi}

Penentuan besarnya kompensasi yang diberikan ditentukan oleh factor-faktor di bawah ini yaitu ( Simamora : 2004 )

Harga/ Nilai Pekerjaan

Penilaian harga suatu jenis pekerjaan merupakan tindakan pertama yang dilakukan dalam menentukan besarnya kompensasi yang akan diberikan kepada karyawan. Penilaain harga pekerja dapat dilakukan dengan dua cara, sebagai berikut:

- Melakukan analisis jabatan/pekerjaan

- Melakukan survei "harga" pekerjaan sejenis pada organisasi lain. 


\section{Sistem Kompensasi}

Beberapa sistem kompensasi yang biasa digunakan adalah :

1). Sistem Prestasi

2). Sistem waktu

\section{Faktor faktor yang mempengaruhi Kompensasi}

\section{Faktor Intern Organisasi}

Faktor intern organisasi yang mempengaruhi besarnya kompensasi adalah:

1). Dana Organisasi

2). Serikat Pekerja

Faktor Pribadi Karyawan, terdiri dari :

1). Produktivitas kerja

2). Posisi dan Jabatan.

3). Pendidikan dan Pengalaman

4). Jenis dan sifat pekerjaan

\section{Faktor Eksternal}

1). Penawaran dan permintaan kerja

2). Biaya hidup

3). Kebijaksanaan Pemerintah

4). Kondisi perekonomian Nasional

Tantangan yang mempengaruhi kebijakan kompensasi

1) Supplai dan permintaan tenaga kerja

2) Produktivitas

3) Kesediaan untuk membayar

4) Berbagai kebjaksanaan pengupahan dan penggajian

5) Kendala kendala pemerintah

Pengertian Lingkungan Kerja

Menurut Nitisemitro (1996: 25)
1. Jenis jenis Lingkungan Kerja

2. Bagian Lingkungan Kerja

3. Indikator Lingkungan Kerja

Pengertian Kinerja Karyawan

1. Penilaian Kinerja

2. Tujuan Penilaian Kerja

3. Manfaat Penilaian Kerja

4. Unsur nsur yang digunakan dalam penilaian Kerja

\section{Penelitian terdahulu}

Beberapa rujukan teoritis yang diperlukan untuk menunjang penelitian ini adalah :

1) Penelitian Puryanto dengan judul Analisis faktor yang mempengaruhi kinerja karyawan pada STISIP Kartika Bangsa Yogyakarta

2) Penelitian Susdiana dengan judul Pengaruh Pemberian penghargaan kerja terhadap loyalitas karyawan pada Perusahaan industry mebel rotan di Serenan Sukoharjo

3) Penelitian Harto Sumardi dengan judul Analisa Faktor Lingkungan kerja dan Latar belakang pendidikan terhadap kinerja karyawan pada Koperasi

\section{METODOLOGI PENELITIAN}

\section{Jenis Penelitian}

Jenis penelitian yang digunakan adalah deskriptif kualitatif dan deskriptif kuantitatif. Untuk mendeskripsikan jawaban responden tentang pengaruh kompensasi dan Lingkungan kerja terhadap kinerja karyawan CV. Roda Jati Karanganyar sedangkan untuk membuktikan hipotesis penelitian tentang 
ada tidaknya pengaruh kompensasi dan lingkungan kerja terhadap kinerja karyawan CV. Roda Jati Karangnayar digunakanan analisis Regresi Berganda.

\section{Metode Pengumpulan Data}

Dalam penelitian ini terdiri dari data primer, yaitu data yang berasal dari sumber utama yaitu karyawan CV. Roda Jati Karanganyar. Selain itu juga digunakan data sekunder, yaitu merupakan data yang diperoleh dengan proses pengolah lebih lanjut. Sedangkan teknik pengumpulan data dalam penelitian ini dengan cara Kuesioner. Kuesioner yaitu penyebaran angket kuesioner tertutup berupa daftar pertanyaan mengenai masalah yang akan diteliti yang ditujukan kepada mahasiswa yang menjadi sampel penelitian. Daftar berisi pertanyaanpertanyaan tentang pokok permasalahan yang diteliti.

\section{Instumen Penelitian}

Instrumen yang digunakan dalam penelitian ini adalah skala interval atau skala yang berjenjang. Untuk penetuan bobot atau skor tentang variable variable yang mempengaruhi produktivitas. Dalam penelitian ini digunakan metode skala likert yang dibagi dalam lima jenjang yaitu :

- Jawaban sangat setuju = Skor 5

- Jawaban setuju = Skor 4

- Jawaban netral= Skor 3

- Jawaban tidak setuju $=$ Skor 2

- Jawaban sangat tidak setuju = Skor 1
Sedangkan untuk menilai valid tidaknya kuesioner dan reliabel tidaknya kuesioner digunakan uji validitas dan uji realibilitas.

Dalam penelitian ini terdiri dari data primer, yaitu data yang berasal dari sumber utama yaitu karyawan CV. Roda Jati Karanganyar. Selain itu juga digunakan data sekunder, yaitu merupakan data yang diperoleh dengan proses pengolah lebih lanjut. Sedangkan teknik pengumpulan data dalam penelitian ini dengan cara Kuesioner. Kuesioner yaitu penyebaran angket kuesioner tertutup berupa daftar pertanyaan mengenai masalah yang akan diteliti yang ditujukan kepada dosen dan karyawan yang menjadi sampel

\section{Metode Analisa Data}

1. Uji Instrumen

a. Uji Validitas

Analisis validitas merupakan analisa yang dilakukan untuk mengukur apakah instrumen yang digunakan dalam penelitian benar-benar mampu mewakili semua aspek yang dianggap sebagai kerangka konsep. Pengujian validitas menggunakan uji korelasi product moment Pearson dengan bantuan Program SPSS. Instrumen dikatakan valid jika angka $r$ hitung $>r$ tabel.

b. Uji Reliabilitas

Uji Reliabilitas digunakan untuk mengukur bahwa instrumen peneltian bebas dari kesalahan persepsi sehingga menghasilkan hasil yang konsisten dan dapat digunakan pada kondisi yang 
berbeda-beda. Pengujian reliabilitas menggunakan Cronbach alpha dengan program SPSS. Dikatakan reliabel jika nilai Cronbach alpha > 0,6 Rumus koefisien alpha: (Umar,2003:90).

2. Analisis Regresi Berganda

Analisa yang akan dilakukan dalam penelitian ini adalah analisa regresi linear berganda dengan rumus sebagai berikut:

$Y=a+b 1 . X_{1}+b_{2} X_{2}+e$

Keterangan:

$\mathrm{Y}=$ Kinerja Karyawan

$\mathrm{a}=$ Konstanta

$\mathrm{X}_{1}=$ Kompensasi

$\mathrm{X}_{2}=$ Lingkungan Kerja

$\mathrm{b}_{1}, \mathrm{~b}_{2}=$ Koefisien variabel independen $\mathrm{X}_{1}$, $\mathrm{X}_{2}$

e $\quad=$ Error

3. Uji Hipotesis

a. Uji t

Uji $t$ ini digunakan untuk menguji pengaruh masing-masing variabel independen (kompensasi, lingkungan kerja) terhadap variabel dependen (kinerja karyawan).

Untuk mengetahui diterima atau ditolaknya Ho, maka hasil perhitungan signifikansi ( nilai sig) dibandingkan dengan level of significant 0,05 . Apabila nilai sig $<0,05$, maka Ho ditolak, yang berarti ada pengaruh yang signifikan variabel independen terhadap variabel dependen dan sebaliknya apabila nilai sig $>0,05$, berarti terdapat pengaruh tidak signifikan variabel independen terhadap variabel dependen

b. Uji F

Uji ini dilakukan dengan program SPSS. Uji ini digunakan untuk menguji keberartian koefisien regresi secara bersama - sama / serentak. Untuk mengetahui diterima atau ditolaknya Ho, maka hasil perhitungan signifikansi ( nilai sig) dibandingkan dengan level of significant 0,05 . Apabila nilai sig < 0,05, maka Ho ditolak, yang berarti ada pengaruh yang signifikan variabel independen terhadap variabel dependen dan sebaliknya apabila nilai sig > 0,05, berarti terdapat pengaruh tidak signifikan variabel independen terhadap variabel dependen.

c. $\quad \mathrm{jii} \mathrm{R}^{2}$

Uji ini dilakukan untuk mengetahui berapa besar pengaruh variabel independen terhadap variabel dependen.

\section{PEMBAHASAN}

\section{Uji Instrumen}

\section{Uji Validitas Instrumen}

Uji validitas dimaksudkan untuk mengetahui sahih tidaknya butir pertanyaan yang diajukan. Suatu angket dikatakan valid (sah) jika pertanyaan pada suatu angket mampu untuk mengungkapkan sesuatu yang akan diukur oleh angket tersebut. Penentuan validitas menggunakan pengukuran berdasar pada koefisien korelasi product moment.

Jika nilai $r$ hitung positif dan lebih besar dari $r$ tabel, maka butir yang diuji dinyatakan valid. 
Tetapi jika nilai $r$ hitung lebih kecil dari $r$ tabel atau bertanda negatif, maka butir yang diuji dinyatakan tidak valid, dan harus dikeluarkan dari proses analisis berikutnya.

Variabel Kompensasi (X1)

Berdasarkan hasil uji Validitas dengan SPSS, diketahui bahwa ke-5 item pernyataan variabel Kompensasi (X1) dinyatakan valid. Hal ini dikarenakan ke-5 item pernyataan mempunyai $\mathrm{r}$ hitung $>\mathrm{r}$ tabel $(\mathrm{n}=50, \alpha=$ $0,05>0,279$ ); maka ke-5 item pernyataan variabel Kompensasi (X1) valid atau sahih. Jadi ke-5 item pernyataan variable kompensasi (X1) dapat dilanjutkan uji reliabilitasnya.

Variabel Lingkungan kerja (X2)

Berdasarkan hasil Uji Validitas dengan SPSS, diketahui bahwa ke-5 item pernyataan variabel lingkungan kerja (X2) dinyatakan valid. Hal ini dikarenakan ke-5 item pernyataan mempunyai $\mathrm{r}$ hitung $>\mathrm{r}$ tabel $(\mathrm{n}=$ $50, \alpha=0,05>0,279)$; maka ke-5 item pernyataan variable lingkungan kerja (X2) valid atau sahih. Jadi ke-5 item pernyataan variabel lingkungan kerja (X2) dapat dilanjutkan uji reliabilitasnya.

Variabel Kinerja Karyawan (Y)

Berdasarkan hasil Uji Validitas dengan SPSS, diketahui bahwa ke-5 item pernyataan variabel Kinerja Karyawan (Y) dinyatakan valid. Hal ini dikarenakan ke-5 item pernyataan mempunyai $\mathrm{r}$ hitung $>\mathrm{r}$ tabel $(\mathrm{n}=$ 50, $\alpha=0,05>0,279)$; maka ke-5 item pernyataan variable Kinerja Karyawan (Y) valid atau sahih. Jadi ke-5 item pernyataan variabel Kinerja Karyawan

(Y) dapat

\section{Uji Reliabilitas.}

Hasil pengujian reliabilitas instrumen variabel diperoleh hasil sebagai berikut : Kompensasi $\left(\mathrm{X}_{1}\right)$ menunjukkan Nilai Cronbach $\alpha$ sebesar 0, 9181 lebih besar dari nilai batas 0.6, Lingkungan kerja (X2) menunjukkan Nilai Cronbach $\alpha$ sebesar 0, 7857 lebih besar dari nilai batas 0,6 dan Kinerja karyawan ( Y ) menunjukkan Nilai Cronbach $\alpha$ sebesar 0, 9283 lebih besar dari nilai batas 0,6 sehingga variabel bebas kompensasi dan lingkungan kerja serta variabel kinerja karyawan dinyatakan reliable

\section{Uji Hipotesis}

Pengujian hipotesis dalam penelitian ini menggunakan analisis regresi, uji $t$ dan uji $F$. Analisis regresi adalah analisis untuk mengetahui pengaruh Kompensasi $\left(\mathrm{X}_{1}\right)$, Lingkungan kerja (X2) terhadap Kineja Karyawan (Y). Berdasarkan hasil regresi dari data primer yang diolah dengan menggunakan program SPSS 19 for windows diperoleh hasil sebagai berikut :

\section{Analisis Regresi Linier Berganda}

Dari hasil perhitungan dengan menggunakan program SPSS Versi 19 for windows, terhadap variabel-variabel yang disebutkan diatas maka dapat diketahui pada hasil regresi sebagai berikut:

$Y=0,819+0,274 X 1-2,040 X 2$

Dari persamaan regresi diatas diketahui bahwa nilai koefisien regresi adalah variabel 
Kompensasi (X1) bertanda positif terhadap variabel Kinerja Karyawan )sedangkan variabel Lingkungan kerja (X2) tidak berpengaruh positif terhadap variabel Kinerja Karyawan (Y)

\section{Uji Pengaruh Serempak (Uji F)}

Uji F merupakan perhitungan untuk mengetahui apakah variabel independen yang terdiri dari variabel-variabel Kompensasi $\left(\mathrm{X}_{1}\right)$ dan Lingkungan kerja (X2), secara simultan atau serempak mempunyai pengaruh yang signifikan terhadap variabel dependen dalam hal ini adalah Kinerja Karyawan (Y). Dari analisis diperoleh hasil sebagai berikut

Hasil uji secara serempak (Uji F) diketahui besarnya nilai $\mathrm{F}=524,795$ signifikansi 0,000 $<0,05$. Sehingga dapat disimpulkan secara bersama-sama variabel bebas mempengaruhi Keputusan mahasiswa.

\section{Uji Pengaruh Parsial ( Uji t )}

Berdasarkan hasil pengujian yang telah dilakukan Persamaan dapat dijelaskan hal - hal berikut:

\section{Pengaruh Kompensasi terhadap Kinerja Karyawan}

Hasil pengujian regresi yang dilakukan menunjukkan untuk variabel program studi mempunyai nilai signifikansi $0,015<0,05$ artinya variabel kompensasi mempunyai pengaruh signifikan terhadap Kinerja Karyawan. Kesimpulan dari pengujian ini Hipotesis terbukti.

\section{Pengaruh Lingkungan Kerja terhadap Kinerja Karyawan}

Hasil pengujian regresi yang dilakukan menunjukkan untuk variabel lingkungan kerja mempunyai nilai signifikansi $0,702>0,05$ artinya variabel lingkungan kerja tidak ada pengaruh signifikan terhadap Kinerja karyawan Kesimpulan dari pengujian ini Hipotesis tidak terbukti

\section{Uji $\mathbf{R}^{2}$ (Koefisien Determinasi)}

Koefisien determinasi ini untuk mengetahui besarnya sumbangan pengaruh variabel bebas (Kompensasi dan Lingkungan kerja ) terhadap variabel dependen (Kinerja Karyawan ) yang ditunjukkan dengan besarnya $\mathrm{R}^{2}$. Hasil perhitungan koefisien determinasi dapat dijelaskan sebagai berikut ini.

Berdasarkan hasil analisis seperti yang tersaji pada Tabel diatas dapat diketahui bahwa nilai koefisien determinasi (Adjusted $R$ Square) sebesar 0,977atau 97,7\%. Hal ini berarti variabel Kompensasi $\left(\mathrm{X}_{1}\right)$ dan Lingkungan Kerja (X2) memberikan konstribusinya sebesar 97,7 \% terhadap Kinerja Karyawan Sedangkan sisanya sebesar $0,3 \%$ dipengaruhi oleh variabel lain diluar penelitian ini.

\section{KESIMPULAN}

Berdasarkan hasil analisis data dan pengujian hipotesis yang telah dilakukan maka dapat ditarik kesimpulan sebagai berikut: 
Berdasarkan hasil analisis data dan pengujian hipotesis yang telah dilakukan maka dapat ditarik kesimpulan sebagai berikut:

a. Kompensasi mempunyai pengaruh yang signifikan terhadap Kinerja Karyawan di CV Roda Jadi Karanganyar

b. Lingkungan Kerja tidak mempunyai pengaruh yang signifikan terhadap Kinerja Karyawan di CV Roda Jati Karanganyar

c. Terdapat pengaruh yang signifikan secara simultan antara variabel independen yang terdiri dari variabel kompensasi dan Lingkungan kerja terhadap Kinerja Karyawan di CV Roda Jati Karanganyar

\section{DAFTAR PUSTAKA}

Alex S. Nitisemitro, 1996, Manajemen Personalia (Manajemen Sumber Daya Manusia), Cetakan 9 edisi ketiga,Jakarta, Ghalia Indonesia

Algifari, 2003, Statistik Induktif, Yogyakarta, UPP AMP YKPN

Anwar Prabu Mangkunegara, 2000, Manajemen Sumber Daya Manusia Perusahaan, B andung, Penerbit PT. Remaja Rosdakarya

Fuad Mas'ud, 2004, Survai Diagnosis Organizational (Konsep dan Aplikasi), Badan Semarang, Penerbit Universitas Diponegoro

Ghozali, Imam, 2006, Aplikasi Analisis Multivariate dengan Program SPSS,
Badan S e marang, Penerbit Universitas Diponegoro

Gomes, Faustino Cardoso, 2003, Manajemen Sumber Daya Manusia, Yogyakarta, Andi Offset

Hadawi Nawawi, 2001, Manajemen Sumber Daya Manusia Untuk Bisnis Yang Kompetitif, Cetakan Keempat, Yogyakarta, Gadjah Mada University Press

.Hadi, Sutrisno, 2001, Statistik, Yogyakarta, Andi Offset

Hani, Handoko, 2000, Manajemen Personalia dan Sumber Daya Manusia, Yogyakarta, BPFE,

Hasibuan, Malayu S. P, 2000, Manajemen Sumber Daya Manusia, Jakarta, Bumi Aksara

Hasibuan, Malayu S.P, 2002, Manajemen Sumber Daya Manusia,Jakarta, Bumi Aksara

Husein Umar, 2004, Sumber Daya Manusia Dalam Organisasi, Jakarta, PT. SUN.

Mathis, dan Jackson, 2000, Manajemen Sumber Daya Manusia, Jakarta, Salemba Empat

Rivai, Veithzal, 2005, Manajemen Sumber Daya Manusia untuk Perusahaan, Raja k a rta, Grafindo Persada

Santoso, Singgih, 2003, Statistik Deskriptif (Konsep dan Aplikasi dengan Micosoft Excel dan SPSS), Yogyakarta, Andi Offset 
Pengaruh Kompensasi Dan Lingkungan Kerja Terhadap

Kinerja Karyawan Pada Cv. Roda Jati Karanganyar Tahun 2016

ISSN : 1412-629X

Simamora, Henry, 2004, Manajemen Sumber Daya Manusia, STIE YKPN, Yogyakarta.

Sugiyono, 2003, Metode Penelitian Bisnis, $\mathrm{CV}$. Alfabeta, Bandung. 